\title{
In-Silico Investigation of Luminol, Its Analogues and Improved Mechanism of Chemiluminescence for Blood Identification Beyond Forensics
}

\author{
Toluwase Hezekiah Fatoki \\ Department of Biochemistry, Federal University Oye-Ekiti, PMB 373, Oye-Ekiti, Ekiti State, \\ Nigeria.
}

Corresponding Author Email: hezekiahfatoki@gmail.com

\begin{abstract}
This study aimed to discover chemiluminescent analogues of luminol, understand their molecular binding to hemoglobin of bloodstains in the household crime, and the mechanism of chemiluminescence. Similarity and clustering analyses of luminol analogues were conducted, and molecular docking was carried out on hemoglobin from Homo sapiens and other four domestic organism namely Gallus gallus, Drosophila melanogaster, Rattus norvegicus, and Canis familiaris. The results show that the order of overall binding score is D. melanogaster > $H$. sapiens > C. familiaris > R. norvegicus > G. gallus. Seven compounds namely ZINC16958228， ZINC17023010， ZINC19915427， ZINC34928954， ZINC19915369, ZINC19915444, and ZINC82294978, were found to be consistently stable in binding to diverse hemoglobin and possibly have chemiluminescence than luminol. The amino acid residues involved in the interaction of human hemoglobin with the 30 test compounds, show that His45, Lys61, Asn68, Val73, Met76, Pro77, Ala79, Ala82, Leu83, Pro95, Phe98, Lys99, Ser102, Ser133, Ala134, and Thr134 are significant in the mechanism of action of presumptive test compounds. The improved mechanism of chemiluminescent identification of blood hypothesized that nitrite interact with the Fe(II) heme, with the cleavage of a hydroxide ion and the formation of the nitrosonium cation in peroxidase reaction. It was proposed that degradation of rhombic heme complex to fluorescent products is possibly inhibited by nitric oxide from the test compound luminol. This study provides novel insight on the luminol and its actual mechanism for broader possible applications of luminol with careful development of new methodologies.
\end{abstract}

Keywords: Luminol, analogues, docking, hemoglobin, chemiluminescence, mechanism design 


\section{INTRODUCTION}

Forensic biology is an aspect of forensic science that comprises of serology and deoxyribonucleic acid (DNA) analyses. Forensic science is the application of science to the criminal and civil laws that are enforced by police agencies in a criminal justice system (Saferstein, 2011; Fatoki, 2016). In the forensic investigation laboratory, serology analysis deals with the screening of evidence for the presence of body fluids (such as bloodstains, saliva and semen) while DNA profiling is used to pinpoint body fluids to a specific organism or living being. However, the strengths and present limitations of DNA profiling have been presented (Fatoki, 2016).

Blood is an important body fluid that is required for living systemic activities and consists of many components (cells, hemoglobin, proteins antibody, clotting factor etc), useful for metabolic profiling in relevance to forensic toxicology and forensic pathology. The identification of blood is central to many homicide, aggravated assault, sexual assault, and burglary investigations. The presence of blood on evidentiary items can be critical in establishing guilt or innocence during criminal proceedings while blood spatter interpretation provides the manner in which blood was deposited (Gefrides and Welch, 2011). Blood as a crime evidence can be identified through reagents that act on hemoglobin and its derivatives (proteins and amino acids). Due to its immutable and nontransferable characteristics, these components are capable of identifying the origin of evidence (da Silva, 2012).

Luminescence refers to the emission light which occurs when a molecule in an excited state relaxes to its ground state and various types of luminescence differ from the source of energy to obtain the excited state (Dodeigne et al., 2000). In chemiluminescence, the energy is produced by a chemical reaction. Luminol (5-amino-2,3-dihydro-1,4-phthalazinedione), is a chemical that has found application in forensic, environmental, biomedical, and clinical sciences (Khan et al., 2014). Luminol is used most commonly at crime scenes to reveal bloodstains that are not readily, apparent to the naked eye. The chemiluminescence of luminol is catalyzed by the haemoglobin in blood and it has been used as a very sensitive forensic test for blood (Quickenden et al., 2004; Arruda-Vasconcelos et al., 2017). Luminol can react vigorously with selected classes of reagents which include strong reducing agents, strong oxidizing agents, strong acids, and strong bases. Report has shown that in aprotic media (dimethylsulphoxide or dimethylformamide), only 
oxygen and a strong base are required for luminol chemiluminescence while in protic solvents (water, water solvent mixtures or lower alcohols), various oxygen derivatives (molecular oxygen, peroxides, superoxide anion) can oxidize luminol derivatives but required catalyst either enzymes or by mineral catalysts (Dodeigne et al., 2000).

Most laboratories also use phenolphthalein, tolidine, tetramethylbenzidine, or leucomalachite green for preliminary blood identification testing (Gaensslen, 2000). The derivatives of isoluminol has been found to reactive to some extent include aminoethylethylisoluminol (AEEI), aminobutylethylisoluminol (ABEI) and aminobutylethylnaphthalhydrazide (ABENH) (Dodeigne et al., 2000). Previous research has shown that luminol did not adversely affect the polymerase chain reaction (PCR) during DNA analysis of the bloodstain treated with luminol and that luminol did not interfere with the phenolphthalin and tetramethylbenzidine presumptive tests for blood (Gross et al., 1999; Lee et al., 1989; Hochmeister et al., 1991). However, the major drawbacks to blood detection using luminol are the false-positive results, the lack of specificity, and dark environment conditions (Stoica et al., 2016). Thus, there is a need to identify more stable chemiluminescence compounds.

Although, bioinformatic workflows and methods used in other fields of DNA science has been applied to forensic DNA profiling from high-throughput sequencing (Liu and Harbison, 2018) and forensic reconstruction of high-throughput biological assays (Baggerly and Coombes, 2009), the in silico serological analysis for forensic science application has not been investigated. The aim of this study is to discover chemiluminescent analogues of luminol, predict their molecular binding to hemoglobin of bloodstains in the household crime, and the mechanism of chemiluminescence.

\section{MATERIALS AND METHODS}

\section{Similarity search and clustering analysis}

The structure of luminol was obtained from the PubChem Compound Database in canonical SMILES (Simplified Molecular Input Line Entry Specification) format and was used to query the ZincDrugLike database using Swisssimilarity server (Zoete et al., 2016), to obtained structurally similar compounds (ligands), and they were manually screen for the presence of two ketone functional groups at a similarity score cutoff of 0.800 . The structure of other six compounds for blood test were also obtained, namely; phenolphthalein, O-tolidine, 
tetramethylbenzidine (TMB), leucomalachite green (LMG), aminoethylethylisoluminol (AEEI) and aminobutylethylisoluminol (ABEI). Clustering analysis was performed using ChemMine tools (http://chemmine.ucr.edu/) (Tyler et al., 2011)

\section{Ligand and target protein preparation}

The structure of 25 chemical compounds obtained from similarity search were extracted from the result of SwissSimilarity analysis in SMILES format and converted to MOL2 format using ChemSketch (ACDLabware v2015). The MOL2 files were then converted to protein data bank (pdb) format using PyMol v2.0.7. The crystal structure of Homo sapiens (Human) hemoglobin $\mathrm{Hb}$ ) and $\mathrm{Hb}$ of four other domestic organisms (Gallus gallus, Drosophila melanogaster, Rattus norvegicus, and Canis familiaris), were obtained from the RSCB Protein Data Bank (www.rscb.org).

\section{Molecular Docking Studies}

The molecular docking studies were carried out according to the method of Fatoki et al. (2018). Briefly, all water molecules, hetero atoms, and multichain were removed from the crystal structure of the prepared targets using PyMol v2.0.7. The Gasteiger partial charges were added to the ligand atoms prior to docking. The docking parameter (Table 1) were set up using AutoDock Tools (ADT) v1.5.6 (Morris et al., 2009) and saves the output file of each prepared ligand and each prepared target as pdbqt format. Molecular docking program AutoDock Vina v1.1.2 (Trott and Olson, 2010) was employed to perform the docking experiment from the command line. After docking, the ligands were analyzed and visualized using ADT and PyMol v2.0.7.

\section{Novel insight on mechanism of action of luminol}

The results the previous steps were integrated with available information in available literature through text mining (da Silva et al., 2012; Albertin et al., 1998; Furniss et al., 1989). The mechanism was fine-tuned with existing organic chemistry reactions, and the new mechanism of chemiluminescence of luminol was proposed.

\section{RESULTS AND DISCUSSION}

Crime scene in a vegetative, down-town and rural evironment pose problems with artifacts which are not readily indistinguishable from human bloodstains and most other body fluids. Domestic 
enviroment often features birds, rodents, flies and dog. This neccessitate the need for test compounds that can readily specific to human during crime scene sample analyses.

Clustering of compounds by structural or property similarity can be a powerful approach to correlating compound features with biological activity and it is widely used method for diversity analyses to identify structural redundancies and other biases in compound libraries (Sanni et al., 2017). The result of multi-dimensional scaling (MDS) clustering method provided by ChemMine shows that luminol has chemical fingerprint that differes from other commonly used compounds for presumptiv test for blood. All of the identified analogs of luminol except AEEI (compound 6) were found in different cluster (Figure 1), while ABEI (compound 7) and ZINC12427759 (compound 17).
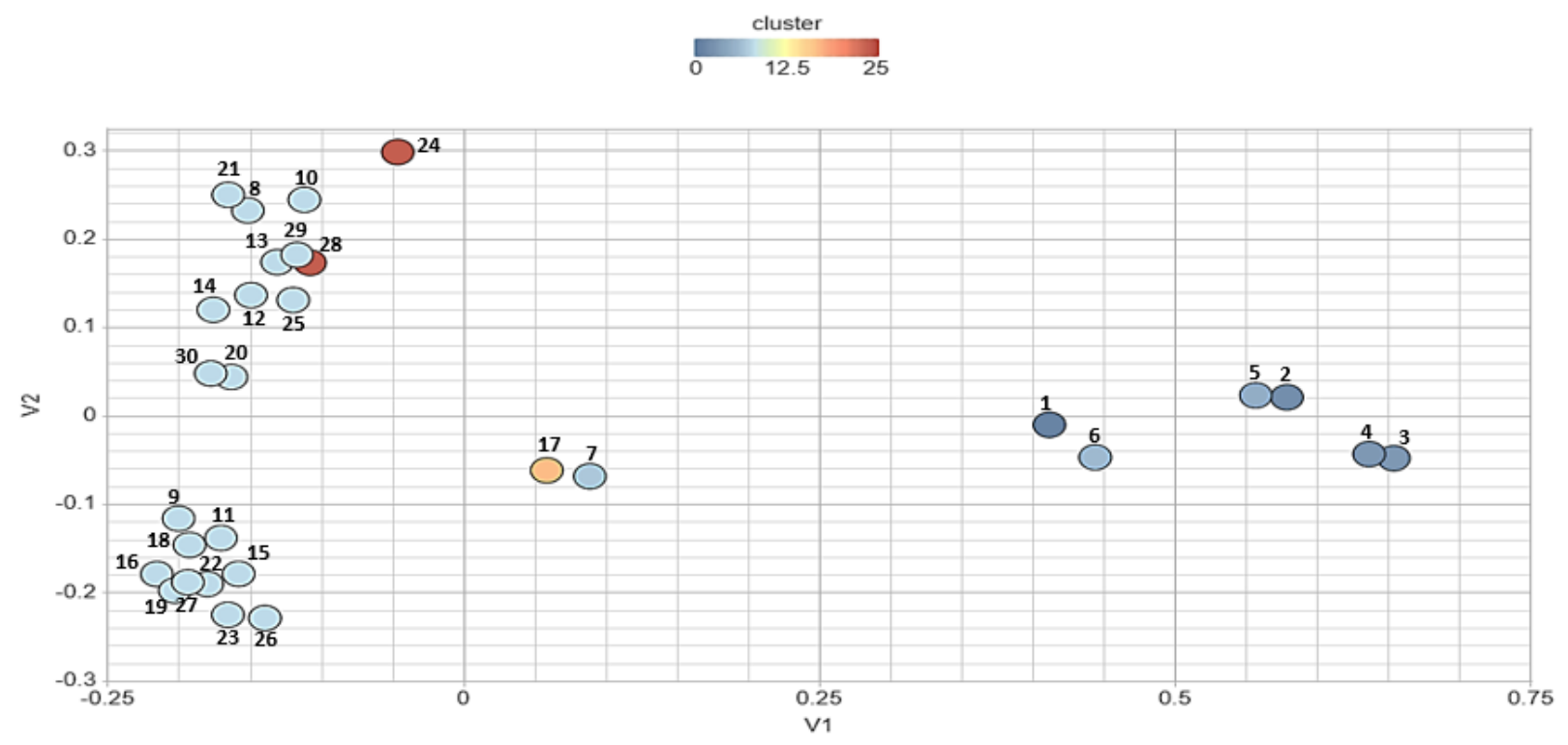

Figure 1: Multi-dimensional scaling clustering (Similarity Cutoff: 0.5, Dimensions: 2D). details of compounds 1-30 are listed in Table 2.

Hemoglobin from Homo sapiens and other four domestic organism namely Gallus gallus, Drosophila melanogaster, Rattus norvegicus, and Canis familiaris, were investigated for their binding to luminol, its analogs and other six compounds used in presumptive test for blood (Table 1 and 2). From the docking result, seven compounds namely ZINC16958228, ZINC17023010, ZINC19915427, ZINC34928954, ZINC19915369, ZINC19915444, and ZINC82294978, were found to be consistently stable in binding to diverse hemoglobin and possibly have chemiluminescence than luminol (Figure 2). The order of overall binding score is 
D. melanogaster $>H$. sapiens $>C$. familiaris $>R$. norvegicus $>$ G. gallus. This shows that $D$. melanogaster can be used as a model organism for forensic research studies without any barrier of ethical permission that often encountered when using human samples.

The Scientific Working Group for Bloodstain Pattern Analysis (SWGSTAIN) has defined insect stains as those bloodstains produced as a result of insect activity (SWGSTAIN, 2008). D. melanogaster has been used as a model system for toxicological studies and diseases mechanism such as neurological disorders, cancer, developmental disorders, metabolic and storage disorders and cardiovascular disease (Bier, 2005; Abolaji et al., 2014; Saraiva et al., 2018). In forensic, D. melanogaster and few other insects provide insights to the degradation state of the body fluid in the crime scene (Leitch et al., 2018; Jiang and Edgar, 2011, Kulstein et al., 2010) and also serve as source of artifacts (Rivers and Geiman, 2017).

Table 1: Docking parameter for Hemoglobin of Human and other four domestic organisms.

\begin{tabular}{|l|l|l|l|l|}
\hline SN & Hemoglobin & Center grid box (points) & Size (points) & Spacing (Å) \\
\hline 1 & $\begin{array}{l}\text { Homo sapiens } \\
\text { (PDB ID: } 1 \text { A3N, Chain A) }\end{array}$ & $5.852 \times 12.788 \times 21.724$ & $120 \times 100 \times 106$ & 0.375 \\
\hline 2 & $\begin{array}{l}\text { Gallus gallus } \\
\text { (PDB ID: } 1 \text { HBR, Chain A) }\end{array}$ & $10.250 \times 4.361 \times 0.514$ & $120 \times 126 \times 104$ & 0.375 \\
\hline 3 & $\begin{array}{l}\text { Drosophila melanogaster } \\
\text { (PDB ID: } 2 \mathrm{BK} 9, \text { Chain A) }\end{array}$ & $2.410 \times-1.515 \times 7.438$ & $126 \times 106 \times 110$ & 0.375 \\
\hline 4 & $\begin{array}{l}\text { Rattus norvegicus } \\
\text { (PDB ID: 3DHT, Chain A) }\end{array}$ & $30.555 \times-22.064 \times 42.068$ & $120 \times 108 \times 110$ & 0.375 \\
\hline 5 & $\begin{array}{l}\text { Canis familiaris } \\
\text { (PDB ID: 3GOU, Chain A) }\end{array}$ & $-16.007 \times-7.061 \times-3.860$ & $116 \times 108 \times 110$ & 0.375 \\
\hline
\end{tabular}


Table 2: Molecular docking score for luminol, analogs of luminol (zinc compounds) and other compounds used in presumptive test for blood.

\begin{tabular}{|c|c|c|c|c|c|c|c|}
\hline \multirow{2}{*}{$\begin{array}{l}\text { Clust } \\
\text { ering } \\
\text { numb } \\
\text { er }\end{array}$} & \multirow[t]{2}{*}{ Ligands } & \multirow[t]{2}{*}{ SMILES } & \multicolumn{4}{|c|}{ Docking Scores (kcal/mol) } & \multirow[b]{2}{*}{$\begin{array}{l}\text { C. } \\
\text { familia } \\
\text { ris } \\
\mathrm{Hb}\end{array}$} \\
\hline & & & $\begin{array}{l}H . \\
\text { sapiens } \\
\mathrm{Hb}\end{array}$ & $\begin{array}{l}\text { G. } \\
\text { gallus } \\
\mathrm{Hb}\end{array}$ & $\begin{array}{l}D . \\
\text { melano } \\
\text { gaster } \\
\mathrm{Hb}\end{array}$ & $\begin{array}{l}R . \\
\text { norvegi } \\
\text { cus } \mathrm{Hb}\end{array}$ & \\
\hline 1 & Luminol & $\mathrm{C} 1=\mathrm{CC} 2=\mathrm{C}(\mathrm{C}(=\mathrm{C} 1) \mathrm{N}) \mathrm{C}(=\mathrm{O}) \mathrm{NNC} 2=\mathrm{O}$ & -5.0 & -5.2 & -5.2 & -5.0 & -4.8 \\
\hline 2 & Phenolphthalein & $\begin{array}{l}\mathrm{C} 1=\mathrm{CC}=\mathrm{C} 2 \mathrm{C}(=\mathrm{C} 1) \mathrm{C}(=\mathrm{O}) \mathrm{OC} 2(\mathrm{C} 3=\mathrm{CC}=\mathrm{C}(\mathrm{C}=\mathrm{C} 3) \mathrm{O}) \mathrm{C} \\
4=\mathrm{CC}=\mathrm{C}(\mathrm{C}=\mathrm{C} 4) \mathrm{O}\end{array}$ & -6.2 & -5.9 & -6.9 & -5.8 & -5.8 \\
\hline 3 & O-Tolidine & $\mathrm{CC} 1=\mathrm{C}(\mathrm{C}=\mathrm{CC}(=\mathrm{C} 1) \mathrm{C} 2=\mathrm{CC}(=\mathrm{C}(\mathrm{C}=\mathrm{C} 2) \mathrm{N}) \mathrm{C}) \mathrm{N}$ & -5.2 & -5.0 & -6.1 & -5.0 & -6.3 \\
\hline 4 & Tetramethylbenzidine & $\mathrm{CC} 1=\mathrm{CC}(=\mathrm{CC}(=\mathrm{C} 1 \mathrm{~N}) \mathrm{C}) \mathrm{C} 2=\mathrm{CC}(=\mathrm{C}(\mathrm{C}(=\mathrm{C} 2) \mathrm{C}) \mathrm{N}) \mathrm{C}$ & -5.7 & -5.4 & -6.1 & -5.7 & -6.1 \\
\hline 5 & Leucomalachite green & $\begin{array}{l}\mathrm{CN}(\mathrm{C}) \mathrm{C} 1=\mathrm{CC}=\mathrm{C}(\mathrm{C}=\mathrm{C} 1) \mathrm{C}(\mathrm{C} 2=\mathrm{CC}=\mathrm{CC}=\mathrm{C} 2) \mathrm{C} 3=\mathrm{CC}= \\
\mathrm{C}(\mathrm{C}=\mathrm{C} 3) \mathrm{N}(\mathrm{C}) \mathrm{C}\end{array}$ & -5.7 & -5.5 & -7.1 & -5.7 & -5.9 \\
\hline 6 & $\begin{array}{l}\text { Aminoethylethylisolumin } \\
\text { ol }\end{array}$ & $\mathrm{CCN} 1 \mathrm{C}(=\mathrm{O}) \mathrm{C} 2=\mathrm{C}(\mathrm{C}=\mathrm{C}(\mathrm{C}=\mathrm{C} 2) \mathrm{N}) \mathrm{C}(=\mathrm{O}) \mathrm{N} 1 \mathrm{C}(\mathrm{C}) \mathrm{N}$ & -5.5 & -4.6 & -6.2 & -4.5 & -5.1 \\
\hline 7 & $\begin{array}{l}\text { Aminobutylethylisolumin } \\
\text { ol }\end{array}$ & $\mathrm{O}=\mathrm{C} 2 \mathrm{C} 1 \mathrm{C}(\mathrm{CCC}(\mathrm{N}) \mathrm{C} 1) \mathrm{C}(=\mathrm{O}) \mathrm{N}(\mathrm{N} 2 \mathrm{C}(\mathrm{N}) \mathrm{CCC}) \mathrm{CC}$ & -5.6 & -4.4 & -6.1 & -5.9 & -5.2 \\
\hline 8 & ZINC08581462 & $\mathrm{NC} 1 \mathrm{CCC} 2 \mathrm{C}(\mathrm{C} 1) \mathrm{C}(=\mathrm{O})[\mathrm{NH}][\mathrm{NH}] \mathrm{C} 2=\mathrm{O}$ & -5.0 & -4.7 & -5.5 & -4.8 & -5.0 \\
\hline 9 & ZINC38916622 & $\mathrm{CNC} 1 \mathrm{CCCC} 2 \mathrm{C} 1 \mathrm{C}(=\mathrm{O})[\mathrm{NH}][\mathrm{NH}] \mathrm{C} 2=\mathrm{O}$ & -5.3 & -5.0 & -5.4 & -4.9 & -5.0 \\
\hline 10 & ZINC02556922 & $\mathrm{S}=\mathrm{C}=\mathrm{NC} 1 \mathrm{CCC} 2 \mathrm{C}(\mathrm{C} 1) \mathrm{C}(=\mathrm{O})[\mathrm{NH}][\mathrm{NH}] \mathrm{C} 2=\mathrm{O}$ & -5.2 & -4.7 & -4.8 & -4.4 & -4.9 \\
\hline 11 & ZINC16958228 & $\mathrm{O}=\mathrm{CNC} 1 \mathrm{CCCC} 2 \mathrm{C} 1 \mathrm{C}(=\mathrm{O})[\mathrm{NH}][\mathrm{NH}] \mathrm{C} 2=\mathrm{O}$ & -5.3 & -5.0 & -5.4 & -5.1 & -6.1 \\
\hline 12 & ZINC17023010 & $\mathrm{O}=\mathrm{C} 1[\mathrm{NH}][\mathrm{NH}] \mathrm{C}(=\mathrm{O}) \mathrm{C} 2 \mathrm{C} 1 \mathrm{CC} 1 \mathrm{CCCCC} 1 \mathrm{C} 2$ & -6.1 & -5.6 & -6.8 & -6.0 & -6.4 \\
\hline 13 & ZINC00168837 & $\mathrm{CN}(\mathrm{C} 1 \mathrm{CCC} 2 \mathrm{C}(\mathrm{C} 1) \mathrm{C}(=\mathrm{O})[\mathrm{NH}][\mathrm{NH}] \mathrm{C} 2=\mathrm{O}) \mathrm{C}$ & -5.1 & -4.7 & -6.1 & -5.1 & -5.8 \\
\hline
\end{tabular}




\begin{tabular}{|c|c|c|c|c|c|c|c|}
\hline 14 & ZINC12358759 & $\mathrm{O}=\mathrm{C} 1[\mathrm{NH}][\mathrm{NH}] \mathrm{C}(=\mathrm{O}) \mathrm{C} 2 \mathrm{C} 1 \mathrm{CCCC} 2$ & -4.6 & -5.1 & -5.6 & -5.0 & -5.4 \\
\hline 15 & ZINC19407454 & $\mathrm{NC}(=\mathrm{O}) \mathrm{NC} 1 \mathrm{CCCC} 2 \mathrm{C} 1 \mathrm{C}(=\mathrm{O})[\mathrm{NH}][\mathrm{NH}] \mathrm{C} 2=\mathrm{O}$ & -6.3 & -4.8 & -5.2 & -5.2 & -6.2 \\
\hline 16 & ZINC19915439 & $\mathrm{CCNC} 1 \mathrm{CCCC} 2 \mathrm{C} 1 \mathrm{C}(=\mathrm{O})[\mathrm{NH}][\mathrm{NH}] \mathrm{C} 2=\mathrm{O}$ & -5.2 & -4.9 & -5.3 & -5.1 & -6.1 \\
\hline 17 & ZINC12427759 & $\mathrm{NC} 1 \mathrm{CCCC} 2 \mathrm{C} 1 \mathrm{C}(=\mathrm{O}) \mathrm{N}(\mathrm{N}(\mathrm{C} 2=\mathrm{O}) \mathrm{C}) \mathrm{C}$ & -4.9 & -4.3 & -5.6 & -4.7 & -5.1 \\
\hline 18 & ZINC19915427 & $\mathrm{CC}(\mathrm{NC} 1 \mathrm{CCCC} 2 \mathrm{C} 1 \mathrm{C}(=\mathrm{O})[\mathrm{NH}][\mathrm{NH}] \mathrm{C} 2=\mathrm{O}) \mathrm{C}$ & -5.3 & -5.2 & -5.4 & -5.2 & -6.4 \\
\hline 19 & ZINC19915435 & $\mathrm{CCCNC} 1 \mathrm{CCCC} 2 \mathrm{C} 1 \mathrm{C}(=\mathrm{O})[\mathrm{NH}][\mathrm{NH}] \mathrm{C} 2=\mathrm{O}$ & -5.3 & -4.9 & -5.7 & -5.0 & -5.9 \\
\hline 20 & ZINC34928954 & $\mathrm{CC}(\mathrm{NC} 1 \mathrm{CCC} 2 \mathrm{C}(\mathrm{C} 1) \mathrm{C}(=\mathrm{O})[\mathrm{NH}][\mathrm{NH}] \mathrm{C} 2=\mathrm{O}) \mathrm{C}$ & -5.3 & -5.1 & -6.2 & -5.6 & -6.2 \\
\hline 21 & ZINC20159958 & $\mathrm{BrC} 1 \mathrm{CCC} 2 \mathrm{C}(\mathrm{C} 1) \mathrm{C}(=\mathrm{O})[\mathrm{NH}][\mathrm{NH}] \mathrm{C} 2=\mathrm{O}$ & -5.2 & -4.4 & -5.5 & -4.8 & -5.3 \\
\hline 22 & ZINC19915369 & $\mathrm{CC}(\mathrm{CNC} 1 \mathrm{CCCC} 2 \mathrm{C} 1 \mathrm{C}(=\mathrm{O})[\mathrm{NH}][\mathrm{NH}] \mathrm{C} 2=\mathrm{O}) \mathrm{C}$ & -5.4 & -5.3 & -5.9 & -5.4 & -6.1 \\
\hline 23 & ZINC40417934 & $\mathrm{ClCC}(=\mathrm{O}) \mathrm{NC} 1 \mathrm{CCCC} 2 \mathrm{C} 1 \mathrm{C}(=\mathrm{O})[\mathrm{NH}][\mathrm{NH}] \mathrm{C} 2=\mathrm{O}$ & -5.8 & -4.8 & -5.6 & -5.5 & -6.7 \\
\hline 24 & ZINC14983542 & $\mathrm{O}=\mathrm{C} 1[\mathrm{NH}][\mathrm{NH}] \mathrm{C} 2 \mathrm{C} 1 \mathrm{CC}(\mathrm{CC} 2)[\mathrm{N}+](=\mathrm{O})[\mathrm{O}-]$ & -4.8 & -4.5 & -5.1 & -4.8 & -5.3 \\
\hline 25 & ZINC00053635 & $\mathrm{CCN}(\mathrm{C} 1 \mathrm{CCC} 2 \mathrm{C}(\mathrm{C} 1) \mathrm{C}(=\mathrm{O})[\mathrm{NH}][\mathrm{NH}] \mathrm{C} 2=\mathrm{O}) \mathrm{CC}$ & -5.1 & -4.9 & -6.2 & -5.5 & -6.1 \\
\hline 26 & ZINC19507141 & $\mathrm{N \# CCC}(=\mathrm{O}) \mathrm{NC} 1 \mathrm{CCCC} 2 \mathrm{C} 1 \mathrm{C}(=\mathrm{O})[\mathrm{NH}][\mathrm{NH}] \mathrm{C} 2=\mathrm{O}$ & -5.0 & -4.7 & -5.0 & -4.8 & -4.7 \\
\hline 27 & ZINC19915444 & $\mathrm{CCC}(\mathrm{NC} 1 \mathrm{CCCC} 2 \mathrm{C} 1 \mathrm{C}(=\mathrm{O})[\mathrm{NH}][\mathrm{NH}] \mathrm{C} 2=\mathrm{O}) \mathrm{C}$ & -5.0 & -5.4 & -5.8 & -5.0 & -6.0 \\
\hline 28 & ZINC59910576 & {$[\mathrm{O}-][\mathrm{N}+](=\mathrm{O}) \mathrm{C} 1 \mathrm{CCCC} 2 \mathrm{C} 1 \mathrm{CN}[\mathrm{NH}] \mathrm{C} 2=\mathrm{O}$} & -5.6 & -4.7 & -5.4 & -5.2 & -5.4 \\
\hline 29 & ZINC82294978 & $\mathrm{OC} 1 \mathrm{CCCC} 2 \mathrm{C} 1 \mathrm{CC} 1 \mathrm{C}(=\mathrm{O})[\mathrm{NH}][\mathrm{NH}] \mathrm{C}(=\mathrm{O}) \mathrm{C} 1 \mathrm{C} 2$ & -5.7 & -5.7 & -6.6 & -5.8 & -6.2 \\
\hline 30 & ZINC32578992 & $\mathrm{CCCNC} 1 \mathrm{CCC} 2 \mathrm{C}(\mathrm{C} 1) \mathrm{C}(=\mathrm{O})[\mathrm{NH}][\mathrm{NH}] \mathrm{C} 2=\mathrm{O}$ & -5.1 & -4.7 & -6.2 & -5.2 & -5.5 \\
\hline
\end{tabular}


The ZINC17023010 (compound 12) which is known as benzo[g]phthalazine-1,4 (2H,3H)-dione, was found to produce chemiluminescence by reaction with hydrogen peroxide in the presence of potassium hexacyanoferrate (III) in an alkaline medium, with low relative chemiluminescence intensities (RCI) than luminol and high relative fluorescence intensities (RFI) than luminol after the chemiluminescence reaction (Yoshida et al., 1999). The fluorescence excitation (Ex) and emission (Em) maxima of ZINC17023010 are $360 \mathrm{~nm}$ and $415 \mathrm{~nm}$ respectively, and thus to generated chemiluminescence at $415 \mathrm{~nm}$ (Yoshida et al., 1999). Insightfully, from the clustering and docking results of compound 12, it could be hypothesized that compounds 20 and 29, which are among selected compounds broad-spectrum binding affinity for hemoglobin (Figure 2), would have better chemiluminescent properties. This confirmed the probability that the analogs of luminol identified in this study might be utilize as chemiluminescence labelling reagents. As it is summarized in Figure 3, the amino acid residues involved in the interaction of human hemoglobin with the 30 test compounds, show that His45, Lys61, Asn68, Val73, Met76, Pro77, Ala79, Ala82, Leu83, Pro95, Phe98, Lys99, Ser102, Ser133, Ala134, and Thr134 are significant in the mechanism of oxidation of presumptive test compounds.



Luminol<smiles>O=CNC1CCCC2C(=O)NNC(=O)C12</smiles>

ZINC16958228

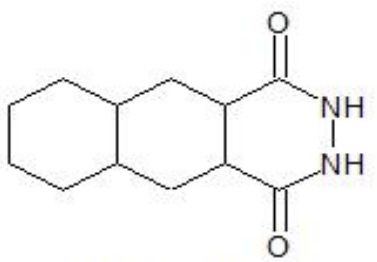

ZINC17023010<smiles>CC(C)NC1CCCC2C(=O)NNC(=O)C12</smiles>

ZINC19915427<smiles>CC(C)NC1CCC2C(=O)NNC(=O)C2C1</smiles>

ZINC34928954<smiles>CC(C)CNC1CCCC2C(=O)NNC(=O)C12</smiles>

ZINC19915369<smiles>CCC(C)NC1CCCC2C(=O)NNC(=O)C12</smiles>

ZINC19915444<smiles>O=C1NNC(=O)C2CC3C(O)CCCC3CC12</smiles>

ZINC82294978

Figure 2: Structure of luminol and its seven predicted stable chemiluminescence analogues. 

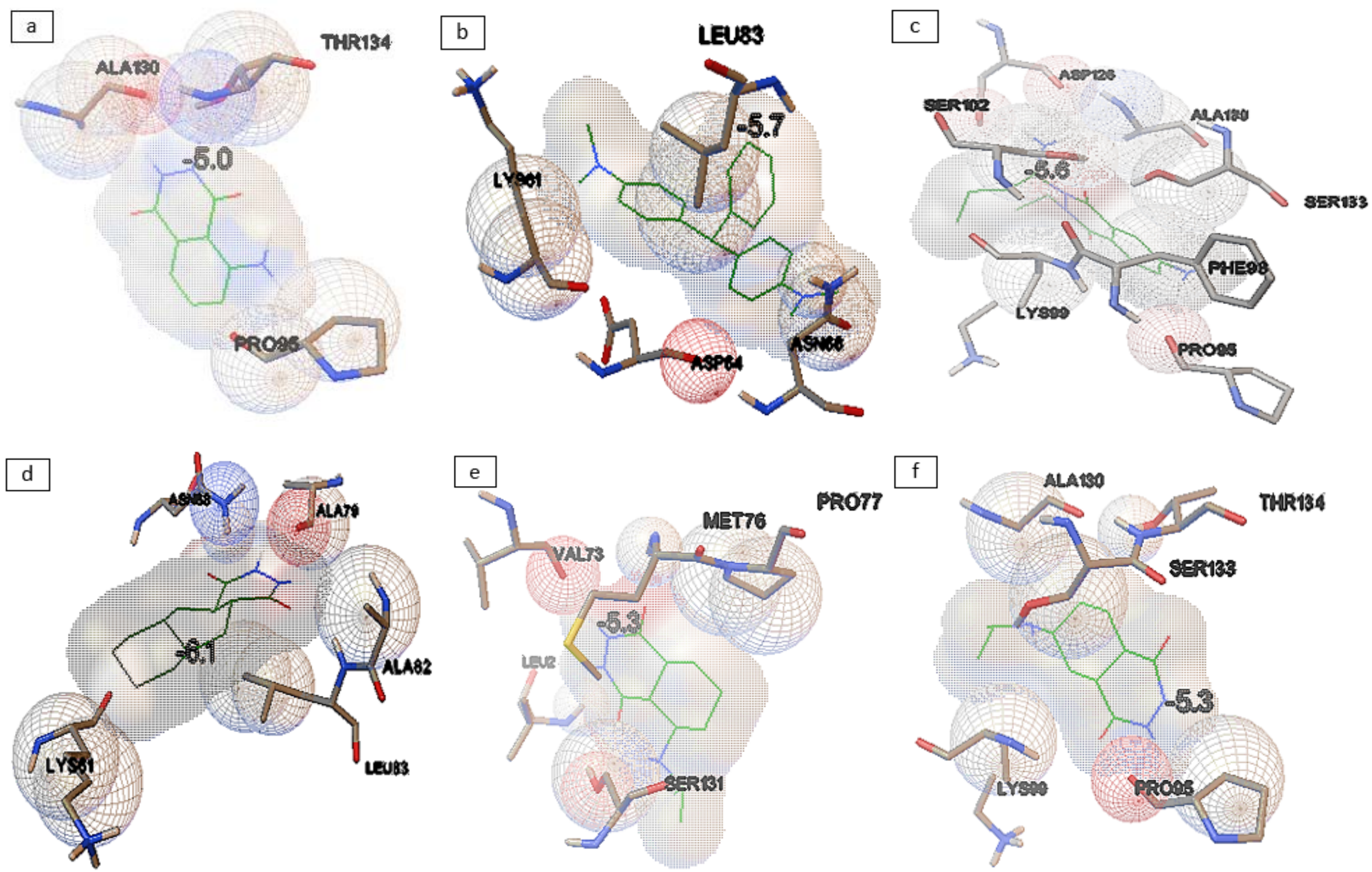

Figure 3: Interaction of human hemoglobin (PDB ID: 1A3N) with (a) Luminol, (b) Leucomalachite green, (c) Aminobutylethylisoluminol, (d) ZINC17023010, (e) ZINC19915427, and (f) ZINC34928954. 
The mechanism of hemoglobin $(\mathrm{Hb})$ and its blood derivatives to enhance the oxidation of luminol in the presence of an alkaline solution, is based on the peroxidase-like activity of hemoglobin (An et al., 2012). However, studied have attempted to improve the reaction of luminol from Weber protocol (Weber, 1996) through the use of natural cyclodextrin and urea (Stoica et al., 2016; Maeztu et al., 2010). Stoica et al. (2016) investigated the influence of $8 \mathrm{M}$ urea pretreatment on the Weber protocol by molecular dynamic simulation and they observed significantly stronger chemiluminescence signal with almost no false-positive reaction.

What is the impact of $\mathrm{NaOH}$ and $\mathrm{H}_{2} \mathrm{O}_{2}$ on the heme oxidation? What is the contribution of test compound (such as luminol) and heme on the color of emitted light? The answers to these questions actually lead to the modification of the existing mechanism of action of luminol provided in this study as shown in Figure 4. Majority of the study on hemoglobin have been in relation to its function as oxygen and carbon (iv) oxide carrier in cellular respiratory process. However, in forensic science, actual mechanism of heme in hemoglobin of the red blood cell in identification of blood as crime sample has not been resolved. A comprehensive study has shown that the oxidation mechanism for luminol is still not completely known due to uncertainty which underlies reaction intermediates (Menezes, 2010). The gap in knowledge could be traced to an oversight in taking into cognizance that heme in the hemoglobin is not just an iron (II) ion but a biological multi-oxidative state iron complex that can be degraded by oxidation. Heme comprise of iron (II) which binds to the center of the porphyrin IX by covalent and coordinate bonding (da Silva et al., 2012). Study has shown that peroxidase-like activity of heme-like compounds called Prussian blue nanoparticles (PBNPs) was higher than that of Fe (III) and that the catalytic capacity of PBNPs did not simply originate from the Fenton reaction (Chen et al., 2018). In addition, the PBNPs were also found to possess catalase-like activity, with the catalytic decomposition of $\mathrm{H}_{2} \mathrm{O}_{2}$ into $\mathrm{H}_{2} \mathrm{O}$ and $\mathrm{O}_{2}$ (Zhang et al., 2016). The result of the study by Chen et al. (2018) implicated the possible presence of $\mathrm{Fe}(\mathrm{IV})=\mathrm{O}$ species in the $\mathrm{FeN} x$ unit assembled by $\mathrm{C} \equiv \mathrm{N}$ ligands.

Report of the mechanism of hemoglobin oxidative degradation through $\mathrm{H}_{2} \mathrm{O}_{2}$ (Rifkind et al., 2003), have shown that nitrite interact with the Fe(II) heme, while the removal of oxygen is necessary for a direct reaction of nitrite with the heme-iron without oxygen bound. The distal histidine is required to protonate the nitrite as it binds (Ranghino et al., 2000), resulting in the cleavage of a hydroxide ion and the formation of the nitrosonium cation bound to the $\mathrm{Fe}(\mathrm{II})$ 
heme. The nitrosonium group is a stronger oxidizing agent than oxygen. As the oxygen pressure is reducing, nitric oxide (NO) production dominates and the NO is more stable, facilitating direct reactions involving $\mathrm{NO}$ but in the presence of oxygen, NO is unstable and exists in the form of $\mathrm{N}_{2} \mathrm{O}_{3}$ and nitrite (Rifkind et al., 2003). The production of labile bioactive NO in the red cell has been attributed to a redox reaction between nitrite produced in the plasma and hemoglobin (Rifkind et al., 2003).<smiles>Nc1cccc2c(=O)[nH][nH]c(=O)c12</smiles>

Luminol

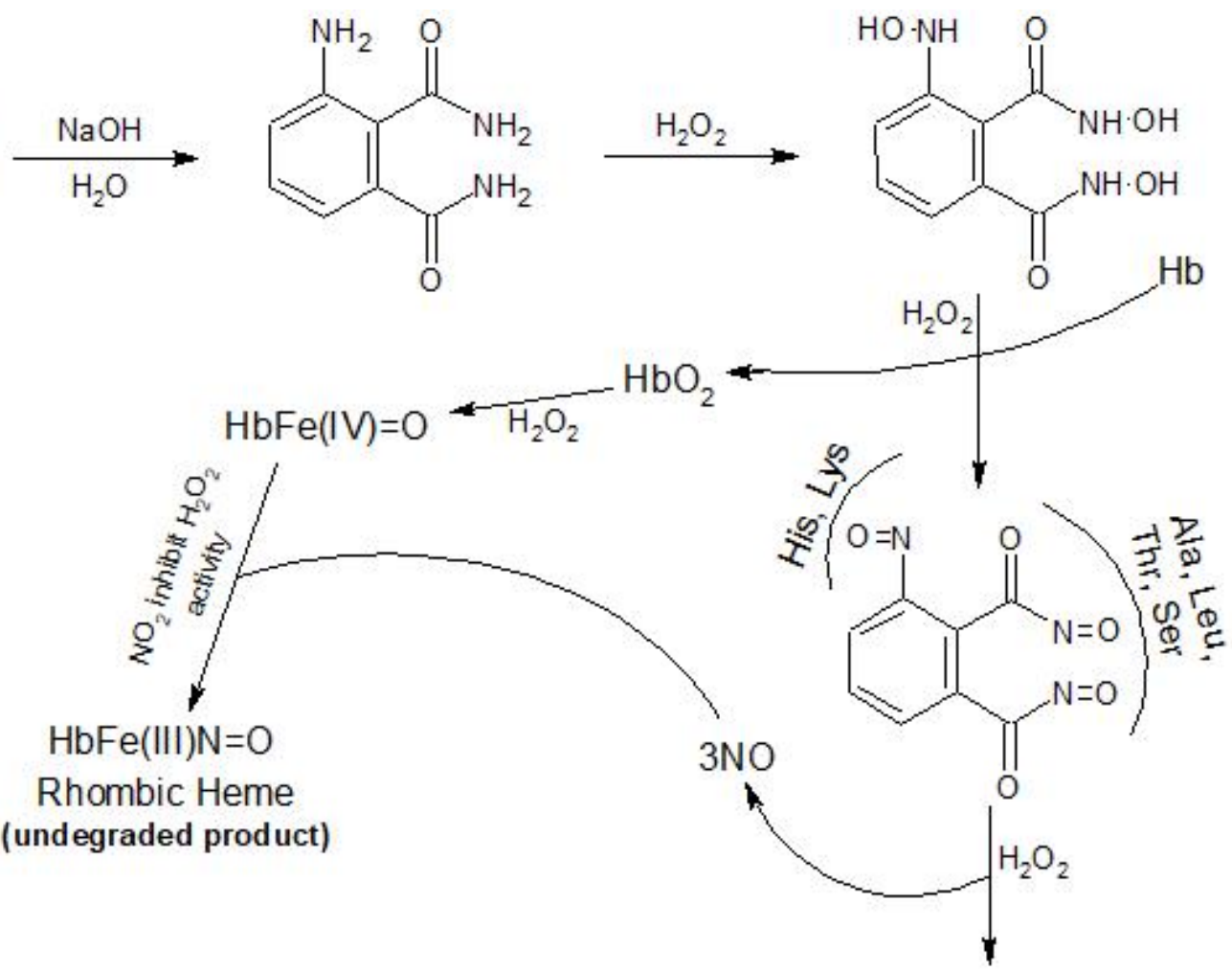<smiles>O=C(O)C1=C(C(=O)O)C(=O)CC=C1</smiles>

ground state

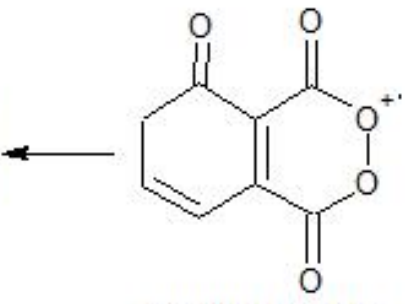

excited state

Figure 4: New hypothetical in-vitro mechanism of chemiluminescent identification of blood with luminol

The cascade begins with the peroxidase reaction which involve $\mathrm{H}_{2} \mathrm{O}_{2}$ with $\mathrm{Fe}$ (II) hemoglobin to produce the highly reactive $\mathrm{Fe}(\mathrm{IV})$ ferrylhemoglobin (ferrylHb), followed by the reaction of a 
second molecule of $\mathrm{H}_{2} \mathrm{O}_{2}$ with ferrylHb to produce a superoxide radical, which can attack the porphyrin before it escapes from the heme pocket (Nagababu and Rifkind, 2000). The initial damaged heme facilitates a change in the tetragonal geometry around the heme resulting in the formation of a high-spin rhombic heme complex (Nagababu et al., 2002). Gradual increase has been observed in the concentration of two fluorescent products, at $10 \mathrm{~min}$ for the $465 \mathrm{~nm}$ fluorescent product (excitation at $321 \mathrm{~nm}$ ) and at above $20 \mathrm{~min}$ for the $525 \mathrm{~nm}$ fluorescent product (excitation of $460 \mathrm{~nm}$ ) (Nagababu and Rifkind, 2000; 1998).

Another study has shown that deoxygenation enhanced the intensity of fluorescence by about 35 and $25 \%$ for the $465 \mathrm{~nm}$ emission band and the $525 \mathrm{~nm}$ emission band respectively, and the binding of carbon monoxide to $\mathrm{Hb}$ resulted in inhibition of about $95 \%$ of the fluorescence in both bands while peroxidase substrates such as ABTS and o-dianisidine completely suppressed the formation of both fluorescent products (Nagababu and Rifkind, 2000). Also, the distinctive roles of catalase and glutathione peroxidase occur at the initial steps of the degradation process and do not react with rhombic heme or fluorescent degradation products (Nagababu et al., 2003). It was reported that heme degradation was inhibited by the addition of catalase which removed hydrogen peroxide even after the maximal level of ferrylHb was reached (Nagababu and Rifkind, 2000). Additionally, study has shown that the formation of the heme fluorescent products during in vivo study involves oxidative stress (Eisinger et al., 1985). The fundamental features of chemiluminescent reaction include spontaneous less exothermic reaction that favors formation of reaction intermediate or product compound in the excited electronic state with emission of light, and its deactivation to the ground energy state (Kai et al., 2001).

\section{CONCLUSION}

This study has provided a novel insight on the possible analogues of luminol present in the existing lead-like chemical database. The results have shown that blood artifacts can come other domestic organisms that are present in the human environment. The possible amino acid residues of hemoglobin that may be involved in the oxidative chemiluminescent reaction are also identified. Furthermore, improved mechanism of chemiluminescence of luminol in relation to heme oxidative degradation in the presence of hydrogen peroxide and alkaline medium was proposed. This will broader the possible applications of luminol with careful development of new methodologies. 


\section{Competing interests}

The author declares that there is no competing interest.

\section{REFERENCES}

Abolaji AO, Kamdem JP, Lugokenski TH, Nascimento TK, Waczuk EP, Farombi EO, Loreto EL, Rocha JB, (2014). Involvement of Oxidative stress in 4 vinylcyclohexene-induced toxicity in Drosophila melanogaster. Free radical Biol. Med., 71: 99-108. DOI: 10.1016/j.freeradbiomed.2014.03.014.

Albertin R, Arribas MAG, Bastos EL, Röpke S, Sakai PN, Sanches AMM, Stevani CV, Umezu IS, Yu J, Baader WJ (1998). Quimiluminescência orgânica: alguns experimentos de demonstração para a sala de aula. Química Nova, 21(6), 772-779.

An JH, Shin KJ, Yang WI, Lee HY, (2012). Body fluid identification in forensics. BMB Rep., 45(10):545-53.

Arruda-Vasconcelos R, Chantre LGF, Lopes RSC, Lopes CC, Barbosa-Ribeiro M, Gomes BPFA, (2017). Application of forensic luminol for blood detection in endodontic files. Revista De Odontologia Da UNESP, 46(4): 227-231. DOI: 10.1590/1807-2577.24916.

Baggerly KA, Coombes KR, (2009). Deriving chemosensitivity from cell lines: forensic bioinformatics and reproducible research in high-throughput biology. Annals of Applied Statistics, 3(4), 1309-1334. DOI: 10.1214/09-AOAS291

Barni F, Lewis SW, Berti A, Miskelly GM, Lago G, (2007). Forensic application of the luminol reaction as a presumptive test for latent blood detection. Talanta, 72, 896-913.

Bier E, (2005). Drosophila, The Golden Bug, Emerges as A Tool for Human Genetics. Nature Reviews - Genetics, 6: 9-23. DOI:10.1038/nrg1503

Chanumolu SK, Rout C, Chauhan RS, (2012). UniDrug-target: a computational tool to identify unique drug targets in pathogenic bacteria. PLoS ONE, 7, e32833.

Chen J, Wang Q, Huang L, Zhang H, Rong K, Zhang H, Dong S. (2018). Prussian blue with intrinsic heme-like structure as peroxidase mimic. Nano Research, 1-9. DOI: $10.1007 / \mathrm{s} 12274-018-2079-8$

da Silva RR, Agustini BC, da Silva ALL, Frigeri HR, (2012). Luminol in the forensic science. Journal of Biotechnology and Biodiversity, 3(4), 172-177.

Daina A, Michielin O, Zoete V, (2017). SwissADME: a free web tool to evaluate pharmacokinetics, druglikeness and medicinal chemistry friendliness of small molecules. Scientific Reports, 7:42717. DOI: 10.1038/srep42717. 
Dodeigne C, Thunus L, Lejeune R, (2000). Chemiluminescence as diagnostic tool. A review. Talanta, 51, 415-439

Eisinger J, Flores J, Tyson JA, Shohet SB, (1985). Fluorescent cytoplasm and Heinz bodies of hemoglobin Koln erythrocytes: evidence for intracellular heme catabolism. Blood 65, 886-893.

Fatoki TH, (2016). Forensic DNA Profiling: Strengths and Limitations (Presentation). Researchgate. DOI: 10.13140/RG.2.2.22002.20161

Fatoki TH, Awofisayo OA, Ogunyewo OA, Ugboko HU, Sanni DM, (2018). Impacts of Analogy and Dimerization of Bioactive Compounds on Molecular Biological Functions. J. Adv. Med. Pharm. Sci. 19(1): 1-14.

Furniss BS, Hannaford AJ, Smith PWG, Tatchell AR, (1989). Vogel's Textbook of Practical Organic Chemistry. 5th Edition, Longman Group UK Limited, pp1-1540.

Gaensslen RE, (2000). Forensic Analysis of Biological Evidence. Chapter 29 In: Wecht CH (editor), Forensic Sciences, vol. 1, Matthew Bender and Co. (Division of Lexis), New York.

Gefrides L, Welch K, (2011). Forensic Biology: Serology and DNA. In: A. Mozayani and C. Noziglia (eds.), The Forensic Laboratory Handbook Procedures and Practice, Springer Science+Business Media, LLC, pp1-37. DOI 10.1007/978-1-60761-872-0_2.

Gfeller D, Michielin O, Zoete V. (2013). Shaping the interaction landscape of bioactive molecules, Bioinformatics, 29:3073-3079.

Gross AM, Harris KA, Kaldun GL (1999). The effect of luminol on presumptive tests and DNA analysis using the polymerase chain reaction. J Forensic Sci., 44(4):837-840.

Hochmeister MN, Budowle B, Baechtel FS, (1991). Effects of presumptive test reagents on the ability to obtain restriction fragment length polymorphism (RFLP) patterns from human blood and semen stains. J Forensic Sci., 36:656-61.

Jiang H, Edgar BA, (2011). Intestinal stem cells in the adult Drosophila midgut. Exp. Cell Res., 317, 2780-2788.

Kai M, Ohta K, Kuroda N, Nakashima K, (2001). Chemiluminescence and Bioluminescence in DNA Analysis. In: Campaña, AMG, Baeyens, WRG (Ed.). Chemiluminescence in analytical chemistry, p. 551-566.

Khan P, Idrees D, Moxley MA, Corbett JA, Ahmad F, von Figura G, Sly WS, Waheed A, Hassan I. (2014). Luminol-Based Chemiluminescent Signals: Clinical and Nonclinical Application and Future Uses. Appl Biochem Biotechnol. 173(2): 333-355. DOI: 10.1007/s12010-014-0850-1.

Kulstein G, Amendt J, Zehner R, (2015). Blow fly artifacts from blood and putrefaction fluid on various surfaces: A source for forensic STR typing. Entomol. Exp. Appl., 157, 255-262. 
Lee HC, Gaenslen RE, Pagliaro EM, Buman MB, Berka KM, Keith TP, et al., (1989). The effect of presumptive test, laten fingerprint and some other reagents and materials on subsequent serological identification, genetic marker and DNA testing in bloodstains. J Forensic Ident., 39:331-50.

Leitch O, Lennard C, Kirkbride KP, Anderson A, (2018). Drosophila melanogaster odorant receptors as volatile compound detectors in forensic science: a proof-of-concept study. Analytical and Bioanalytical Chemistry, 1-8. DOI: 10.1007/s00216-018-1390-2

Liu Y, Harbison S, (2018). A review of bioinformatic methods for forensic DNA analyses. Forensic Science International: Genetics, 33, 117-128. DOI: 10.1016/j.fsigen.2017.12.005

Luo H, Chen J, Shi L, Mikailov M, Zhu H, Wang K, He L, Yang L, (2011). DRAR-CPI: a server for identifying drug repositioning potential and adverse drug reactions via the chemicalprotein interactome. Nucleic Acids Res, 39, W492-W498.

Maeztu R, Tardajos G, Gonzalez-Gaitano G, (2010). Natural cyclodextrins as efficient boosters of the chemiluminescence of luminol and isoluminol: exploration of potential applications. J Phys Chem B. 114(8):2798-806.

Menezes FMC. (2010). Synthesis and Chemiluminescence Studies of Luminol and Derivatives. MSc. Dissertation, Technical University of Lisboa, Spain.

Nagababu E, Chrest FJ, Rifkind JM, (2003). Hydrogen-peroxide induced heme degradation in red blood cells: the respective roles of catalase and glutathione peroxidase. Biochim Biophys Acta, 1620: 211-217.

Nagababu E, Ramasamy S, Rifkind JM, Jia Y, Alayash AI, (2002). Sitespecific cross-linking of human and bovine hemoglobins differentially alters oxygen binding and redox side reactions producing rhombic heme and heme degradation. Biochemistry, 41: 7407-7415.

Nagababu E, Rifkind JM. (1998). Formation of Fluorescent Heme Degradation Products during the Oxidation of Hemoglobin by Hydrogen Peroxide. Biochem Biophys Res Comm, 247, $592-596$

Nagababu E, Rifkind JM, (2000). Reaction of hydrogen peroxide with ferrylhemoglobin: superoxide production and heme degradation. Biochemistry, 39: 12503-12511.

Quickenden TI, Ennis CP, Creamer JI, (2004). The forensic use of luminol chemiluminescence to detect traces of blood inside motor vehicles. Luminescence, 19: 271-277

Ranghino G, Scorza E, Sjogren T, Williams PA, Ricci M, Hajdu J, (2000). Quantum mechanical interpretation of nitrite reduction by cytochrome cd1 nitrite reductase from Paracoccus pantotrophus. Biochemistry, 39:10958-10966.

Rifkind JM, Nagababu E, Ramasamy S, Ravi LB, (2003). Hemoglobin redox reactions and oxidative stress. Redox Report. 8(5): 234-237. DOI 10.1179/135100003225002817 
Rivers D, Geiman T, (2017). Insect Artifacts Are More than Just Altered Bloodstains. Insects 2017, 8, 37-52. DOI:10.3390/insects8020037

Saferstein R, (2011). Criminalistic: An Introduction to Forensic Science. Tenth Edition, Pearson Education, Inc.

Sanni DM, Fatoki TH, Kolawole AO, Akinmoladun AC, (2017). Xeronine Structure and Function: Comparative Mastery of its Mystery. In Silico Pharmacology, 5(8):1-7.

Saraiva MA, Ávila ER, da Silva GF, Macedo GE, et al., (2018). Exposure of Drosophila melanogaster to Mancozeb Induces Oxidative Damage and Modulates Nrf2 and HSP70/83. Oxidative Medicine and Cellular Longevity, Article ID 5456928, 1-11. DOI: $10.1155 / 2018 / 5456928$

Scientific Working Group on Bloodstain Pattern Analysis (SWGSTAIN). Recommended Terminology; I.A.B.P.A. Newsletter: 2008. Available online: http://iabpa.org/uploads/files/iabpa\%20publications/June\%202008\%20News.pdf

Stoica BA, Bunescu S, Neamtu A, Diana Bulgaru-Iliescu D, Foia L, Botnariu EG, (2016). Improving Luminol Blood Detection in Forensics. J Forensic Sci, 1-6. DOI: 10.1111/1556-4029.13141

Tyler WH, Cao BY and Girke T, (2011). ChemMine tools: an online service for analyzing and clustering small molecules. Nucleic Acids Research, 39, W486-W491, Web Server issue. DOI:10.1093/nar/gkr320.

Weber K, (1996). The use of chemiluminescence of Luminol in forensic medicine and toxicology. I. Identification of blood stains. Dtsch Z Gesamte Gerichtl Med. 57(3):41023.

Yoshida H, Ureshino K, Ishida J, Nohta H, Yamaguchi M, (1999). Chemiluminescent properties of some luminol related compounds (II). Dyes and Pigments 41: 177-182.

Zhang W, Hu SL, Yin JJ, He WW, Lu W, Ma M, Gu N, Zhang Y, (2016). Prussian blue nanoparticles as multienzyme mimetics and reactive oxygen species scavengers. J. Am. Chem. Soc., 138, 5860-5865.

Zoete V, Daina A, Bovigny C, Michielin O, (2016). SwissSimilarity: A Web Tool for Low to Ultra High Throughput Ligand-Based Virtual Screening. J. Chem. Inf. Model, 56(8), 1399-1404. 